Volume 1, No. 3, September - December 2016 ISSN: 2503-4235 (p); 2503-4243 (e)

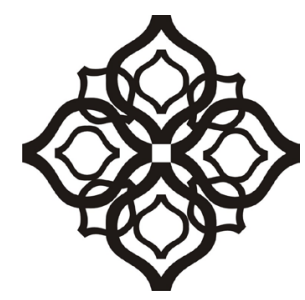

Shirkah

Journal of Economics and Business 


\section{Shirkah}

\section{Journal of Economics and Business \\ Vol. 1, No. 3, September-December 2016 \\ ISSN: 2503-4235 (p); 2503-4243 (e)}

\section{Editor in Chief}

Sri Walyoto

\section{Editorial Boards}

Abu Umar Faruq Ahmad, UBD School of Business and Economics, Brunei Darussalam

Amelia Fauzia, Asia Research Institute, National University of Singapore, Singapore

Cedomir Nestorovic, ESSEC Business School Asia Pacific, Singapore

Dwi Condro Triono, Faculty of Islamic Economics and Business, IAIN Surakarta, Indonesia

Fahmy Radhi, Faculty of Economics and Business Universitas Gadjah Mada, Yogyakarta, Indonesia

Hasan Basri, Syiah Kuala University, Aceh, Indonesia

Jaka Sriyana, Faculty of Economics, Universitas Islam Indonesia, Yogyakarta, Indonesia

Johan Fischer, Department of Social Sciences and Business Roskilde University, Denmark

Masudul Alam Choudhury, Postgraduate Program in Islamic Economics and Finance, Trisakti University, Jakarta, Indonesia and the College of Economics and Political Science (CEPS) in Sultan Qaboos University (SQU), Oman

M. Falik Isbah, School of Humanities and Social Science, University of New South Wales, Australia

M. Ishaq Bhatti, La Trobe Business School Department of Economics and Finance La Trobe University, Australia

Nunung Nurul Hidayah, Aston Business School, Aston University, Birmingham, United Kingdom

Najib Kailani, Pascasarjana, Universitas Islam Negeri (UIN) Sunan Kalijaga, Yogyakarta, Indonesia

Shaikh M Ghazanfar, Departement of Economics, University of Idaho, Russian Federation 
Managing Editors

M. Endy Saputro

M. Zainal Anwar

\section{Assistant to Editor}

Supriyanto

Shirkah Journal of Economics and Business is a peer-reviewed journal published three times a year (January-April, May-August and September-December) by Faculty of Islamic Economics and Business, Institut Agama Islam Negeri (IAIN/ State Institute for Islamic Studies) Surakarta Central Java, Indonesia. The main objective of Shirkah is to offer an academic space of exchange ideas and initiate the increase number of qualified article produced by postgraduate students, practitioners and academicians.

\section{Editorial Office}

Ruang Jurnal Shirkah

Lantai Dasar, Sayap Barat, Fakultas Ekonomi dan Bisnis Islam, IAIN Surakarta

Jln. Pandawa No. 1, Kartasura, Sukoharjo, Jawa Tengah Kode Pos. 57168

Phone (+62271) 781516 Fax: (+62271)782336

E-mail: shirkahiainsurakarta@gmail.com

Website: http://shirkah.or.id/ 



\section{Shirkah}

\section{Journal of Economics and Business}

Vol. 1, No. 3, September-December 2016

ISSN: 2503-4235 (p); 2503-4243 (e)

\section{Table of Contents}

\section{Articles}

Muhfiatun

The Effect of Sharia Monetary Policy and Financing Quality on Financial Performance in Sharia Banking

Roro Hindun

Izzul Fatchu Reza

Understanding Indonesian People Borrowing Money

from Banks and Non-Banking Institutions

M. Nur Rianto Al Arif

299

Monopoly and Ikhtikar in Islamic Economics

Trimulato

Sharia Bank Product Development through Mudhrabah Investment

Aida Nurul Hadiah

Financial Services Authority (OJK) Policy on Debt Proportion and Its Impact on the Profitability of DES Listed Companies in Indonesia

Statement of Financial Accounting Standard (PSAK)

No. 109 and Its Implementation in Several Zakat Management

Organizations in Malang, East Java 



\title{
The Effect of Sharia Monetary Policy and Financing Quality on Financial Performance in Sharia Banking
}

\author{
Muhfiatun \\ Faculty of Islamic Economics and Business, \\ Universitas Islam Negeri Sunan Kalijaga Yogyakarta
}

\begin{abstract}
The purpose of this research is to explain the effect of sharia monetary policy instruments and financing quality on the financial performance of sharia banks. The research sample includes Bank Muamalat Indonesia, Bank Syariah Mandiri, Bank Mega Syariah Indonesia, Bank Rakyat Indonesia Syariah, Bank Syariah Bukopin, BCA Syariah, BNI Syariah, and Bank Jabar Banten Syariah. The financial ratios used in this research are Return on Assets (ROA) and Quick Ratio (QR). The financing qualities used here are murabahah, mudharabah, and musharakah. The sharia monetary policy instruments used are GWM and SBIS. The research uses Partial Least Squares as the data analysis instrument. The research result shows that the financing qualities of mudharabah and musharakah, and SBIS, do not affect ROA, while the variables of murabahah financing and GWM do affect ROA. The variable with significant effect on QR is ROA, as murabahah financing quality; GWM and SBIS; and the other two variables of musharakah and mudharabah do not affect QR. The contribution of the financing quality variables of murabahah, mudharabah, musharakah, GWM and SBIS in explaining the effect on the ROA variable is 0.071 or $7.1 \%$, and the other $92.9 \%$ are affected by other variables not in the current research model. The contribution of murabahah, mudharabah and musyarakah, GWM and SBIS in explaining the effect on QR is 0.7578 or $75.78 \%$ and the remaining $24.22 \%$ is the effect of other variables not in this research model.
\end{abstract}

Keyword: financing quality, sharia monetary policy instrument, financing performance, $R O A$

The development of sharia banking in Indonesia has been rapid, as seen in Bank Indonesia (BI) publications. There were 11 Sharia General Banks (BUS/ Bank Syariah Umum) and 24 sharia business units with total 
assets of Rp. 155.66 trillion in July 2012. The sharia bank market share in March 2012 was $4.1 \%$ with $40.2 \%$ annual growth. The central bank is certain the trend will increase over the next 10 years and the sharia bank market share is forecast to reach $15-20 \%$.

The strict competition among sharia banks and with conventional banks has demanded sharia banks perform well in order to compete in the national banking market in Indonesia. A financial performance evaluation is performed to show financial performance ability using a financial ratio calculation. Financial performance is the description of a sharia bank's financial condition analyzed using financial analysis instruments to show its performance achievement in a certain period (Ermayanti, 2012). The bank's performance is able to be measured with financial report analysis and evaluation. Ratio analysis is categorized into five categories: liquidity ratio, profitability, solvability, activity, and market ratio. The ratios used in this research are profitability ratio and liquidity ratio.

Profitability ratio is the ratio used to determine a bank's ability to make profit. The profitability ratio used in this research is Return on Asset (ROA). ROA is a good measure of profitability due to its focus on a company's ability to gain earnings in all company operations. Sharia banks are not only required to collect large profits in their operations but also to act as intermediation institutions that are obliged to fulfill their short-term obligations. Based on this, this research will also use liquidity ratio as well as profitability ratio. Liquidity ratio is the ratio used to observe a sharia bank's ability to fulfill its short-term obligations. Liquidity ratio is used here to measure a bank's ability to repay its short term debts with flowing assets.

Efforts to continue sharia banks are highly affected by their operating financing investment quality (productive activa). Their good performance and business development must always be in accordance with 
sharia financing quality principles. This research will use the financing quality variables of mudharabah, musharakah and murabahah due to their close relation with the main component of sharia bank productive activa (Puspitasari, 2011, p. 3).

Sharia monetary policy activities are performed in other forms including (i) sharia OPT and (ii) standing facilities sharia (Razali, 2013, p. 23). The Open Market Operation (OPT/ Operasi Pasar Terbuka) based on sharia principles has been made by Bank Indonesia (BI) as the monetary authority that creates the money circulation control instrument in accordance with sharia principles in the form of the Indonesia Bank Sharia Certificate (SBIS/ Sertifikat Bank Indonesia Syariah). Bank Indonesia's support in facilitating monetary instrument availability in accordance with sharia principles will affect the performance of sharia banks. Sharia banks will be able to manage their business portfolios well through the sharia monetary instrument. The sharia monetary instrument is an effort towards open market operations and also affects the liquidity and profitability of sharia banks (Widyastuti, 2009, p. 8). SBIS became one of the research variables in this study.

A sharia bank is a (profit oriented) business institution managed with high trust; therefore, liquidity is important due to the banks' direct relation with the public, customers and the government. Bank Indonesia should maintain GWM at at least 5\% of the Third Party Fund (DPK/ Dana Pihak Ketiga) in rupiah and foreign currency. The GWM policy purpose in sharia banking has close relation with inter-bank traffic management, including central bank instruments to support sharia banks to be more active in investing in real sector. 


\section{Prior Research}

There are several past studies on the underlying concepts related to Islamic banking emphasized in this research. First, is the research by Eka Puspitasari (2011, p. 3) on shari'ah bank financial performance. This research used murabahah financing, SWBI, GWM, ROE, ROA, and CR as variables. The research result shows different categories of murabahah financing, SWBI, and GWM affect FDR, ROA, and ROE as part of sharia bank financial performance. However, they do not have significant effect on average difference of Current Ratio.

Second, the research of Yudi Mulyanto sought to determine the financing quality of murabahah, murabahah, and musharakah on shariah bank rentability. The research result shows: 1) the negative effect of mudharabah financing on rentability, 2) the positive effect of musharakah financing quality on rentability, 3) the positive effect of murabahah on rentability (Mulyanto, 2013, p. 132). Third research study was carried out by A. Rahmat Dimyati to find the financing quality effect on profitability. The variables used in the research were financing quality and profitability. The financing quality is $4.54 \%$ of profitability (Simatupang, 2006, p. viii)

Finally, the research carried out by Aisyah Dewi R. Simatupang on Bank Muamalat Indonesia performance in adapting to economic environment change. Bank performance in her research was represented by the bank's Return on Asset (ROA). The research observing the period of January 2001-December 2005 analyzed the three factors of SWBI, exchange rates, and inflation and showed they have positive effects on Bank Muamalat Indonesia ROA (Dimyati, 2010). This research is a continuation of the research by Eka Puspitasari. The differences are: 1) this research used three derivative variables of financing quality namely mudharabah, musharakah, and murabahah, 2) the research analysis instrument here is Partial Least Square (PLS), whereas Puspitasari's research used ANOVA. 
In addition, the research of Yudi Mulyanto on mudharabah, musharakah, and murabahah financing quality on Bank Muamalat Indonesia is used to strengthen this research.

This research was limited to the financing scope of mudharabah, musharakah and murabahah; and the shari' ah monetary policy instrument only on the Indonesia Bank Shari' ah Certificate (SBIS/ Sertifikat Bank Indonesia Syariah) and Minimum Giro Obligation (GWM/ Giro Wajib Minimum) as the research needs. Based on the explanation above, I am interested to find the effect of sharia monetary policy instrument and financing quality effect on the financial performance of shari'ah banks.

\section{Financial Performance}

Bank performance in general is the reflection of a bank's operational achievements. Bank financial achievement is the description of a bank's financial condition at a certain time related to fund collection and distribution. Bank performance can be measured by analyzing and evaluating a bank's financial report. Ratio is the measurement instrument used by the company to analyze its financial report. The purpose of this analysis is to determine performance efficiency from the company manager financial notes and reports. The financial ratio, as the company's financial position criterion in the future, can be used to make decisions. The ratios used in this research are liquidity ratio and profitability ratio.

Quoting Malvin, Muljono (2002, p. 127) defined liquidity as available fund resources to fulfill all company obligations. Liquidity also means a bank's ability to fulfill the possibility of deposit and savings withdrawals by customers. Banks will qualify as liquid when they are able to fulfill their debt obligations, repay all customer savings, and fulfill financing requirements without delay. Liquidity ratio analysis is the analysis performed to fulfill the bank's short term obligations by the due date. The 
liquidity ratio used in this research is Quick Ratio (CR). QR measures a bank's ability to repay its short term debt with more liquid flowing assets (Suwiknyo, 2009, p. 148)

The bank's performance shows in its net profit. Profitability ratio is the ratio of a company's ability to make profit on selling levels, assets, and certain stocks capital (Suwiknyo, 2009, p. 83) The profitability ratio used in this research is Return on Asset (ROA). The ratio will measure company ability to make net profit based on certain asset levels (Suwiknyo, 2009, p. 83). ROA provides a better measurement of profitability due to its focus on company ability to gain earnings through company operations as a whole.

Mudharabah Financing Quality. The discussion on financing quality, put simply, is more about whether the financing distribution nature is fluent or not. There is more than one perspective to measure this. The first explanation on financing quality is mentioned in PBI No.5/7/ PBI/2003 Article 4, verse 1, which states, "The performed financing quality measurement is based on repayment ability in accordance with main credit repayment provision and/ or ratio achievement between Income Realization (RP/Realisasi Pendapatan) and Income Projection (PP/Proyeksi Pendapatan)" (Bank Indonesia, 2003).

The financing quality, after the measurement process, is distinguished into five groups. It is mentioned in PBI No. 13/13/ PBI/2011 Article 8, Verse 2: "Productive activa quality in the form of financing is distinguished into Fluent, in Special Interest, Less Fluent, Dubious, and Non-performing." (Bank Indonesia, 2011). According to Muhammad (2004), mudharabah financing quality is defined based on "compatibility level of profit sharing realization with its projection, financial condition, and business prospect." According to PBI No.13/13/ PBI/2011 Article 12, "the measurement on Productive Activa Quality in 
the form of mudharabah and musharakah financing is based on repayment ability referring to RBH (Profit Sharing Realization/Realisasi Bagi Hasil) ratio on PBH (Profit Sharing Projection/Proyeksi Bagi Hasil) and/or main repayment promptness" (Bank Indonesia, 2011, p. 27).

Musharakah Financing Quality. Musharakah financing is defined in PBI No.13/13/PBI/2011 Article 1, verse 6, "musharakah financing is financing in the form of banks and its customers' cooperation in certain business, with each party providing a portion of the funds with the provision that the profit will be shared based on the regulation, and the loss will also be borne based on the profit portion of each" (Bank Indonesia, 2011). Musharakah financing quality is a way to find out the musharakah financing condition as productive activa. Musharakah financing quality is explained in PBI No.13/13/PBI/2011 Article 12 which states, "the measurement on productive activa in the form of mudharabah and musharakah financing is based on repayment ability referring to the $\mathrm{RBH}$ (Profit Sharing Realization/Realisasi Bagi Hasil) ratio on PBH (Profit Sharing Projection/ Proyeksi Bagi Hasil) and/or main repayment promptness" (Bank Indonesia, 2011). Musharakah financing categorization is managed in SE No.13/10/ $\mathrm{DPbs}$ categorizing the financing into five groups: fluent, in special attention, less fluent, dubious, and non-performing. The criteria are similar with mudharabah financing due to the similar characteristics, such as profit sharing financing.

Murabahah Financing Quality. Murabahah financing is a contract application in the form of financing distribution by a shariah bank. The definition is stated in PBI No.13/13/PBI/2011 Article 1, verse 7, "murabahah contract based financing which then called murabahah financing is good financing. It explains the selling price to the buyers and the buyers pay a higher price as the agreed profit" (Bank Indonesia, 2011). Sharia banks are unique financial institutions. They reflect on financing 
distribution mechanisms with selling and murabahah. Muhammad (2004) defines murabahah financing quality as "selling credit quality (murabahah) and rent (ijarah) based on repayment ability, financial conditions, and business prospects." Murabahah financing quality categorization is based on its type stated in SE No.13/10/DPbs, which distinguishes it into the five groups of fluent, in special interest, less fluent, dubious, and nonperforming.

Banks are business institutions (profit oriented) managed with high trust, meaning liquidity is a significant matter due to its direct relation with public trust, customers, and the government. The Minimum Obligation Giro (GWM) range in the banking world creates consequences, in particular, conflicts of interest between liquidity and profitability. Bank Indonesia requires banks to maintain a GWM of at least 5\% from the third party fund (DPK/ Dana Pihak Ketiga) in rupiah and foreign currency, as mentioned in the Bank Indonesia regulation No.8/23/PBI/2006 and No.10/23/PBI/2008 on October $16^{\text {th }} 2008$. Other than the regulation, banks with a financing ratio in rupiah over DPK in rupiah less than $80 \%$ should maintain a $1 \%$ GWM in rupiah in addition to the DPK in rupiah (Puspitasari, 2011, p. 27).

Bank Indonesia Sharia Certificates (SBIS/ Sertifikat Bank Indonesia Syariah) are securities based on shari' ah principles in the short term and of rupiah currency published by Bank Indonesia. The SBIS is published by Bank Indonesia using the Jualah contract which is a contract based on a strong prediction of gain. Ju'alah means gift or reward. The etymological meaning is reward or gift to a person due to their work or performance of certain work. The fiqh terminology defines jualahi as "Iltizam (responsibility) in the form of promise of voluntary reward or wages based on work success or providing uncertain service to be performed or produced as the expectation." The contract application in the SBIS transaction is the 
responsibility of Bank Indonesia in the form of a guarantee to give reward equal to the SBI return on shari'ah banks able to distribute their financing above $80 \%$ (Solissa, 2009, p. 31).

\section{Hypothetic Development}

Problematic mudharabah financing will create loss reservation changes which will lead the mudharabah financing into bad financing and reduce sharia bank profitability. However, when mudharabah financing is in good condition, the bank will gain through its main financing repayments and expected profit sharing. This will create good mudharabah financing quality and increase the sharia bank's profitability. The researcher in PBI No. 5/7/PBI/2003 states, "good fund investment quality will create profit." The research also referred to the research by Dimyati $(2010$, p. 1) which states, "[ $\mathrm{t}]$ here is positive relation of financing quality and shari'ah bank profitability." $\mathrm{Ha}=$ mudharabah financing quality has significant positive effect shari'ah bank ROA.

Another form of financing using the profit sharing principle is musharakah financing. This financing is highly dependent on its risk handling due to profit sharing vulnerability. However, the risk is smaller than with mudharabah financing. The logical flow of this financing effect on shari'ah bank profitability is similar to that of mudharabah financing as both involve profit sharing. Similar to Dimyati, Shofa also suggests that " $[\mathrm{t}]$ here is significant positive effect of musharakah profit sharing income on shari'ah bank profitability" (Shofa, 2010, p. i). Ha= Musyārakah financing quality has a significant positive effect on sharia bank ROA.

Murabahah financing quality in general is similar with mudharabah and musharakah financing quality. According to Rosliana, "murabahah financing has positive effect on ROA" (Rosliana, 2008, p. i). Research on murabahah by Utama poses that an increasing murabahah credit balance 
is caused by increasing the distribution of funds using the murabahah principle. This increase will increase the next period repayment installment. The increasing repayment will increase main operation income in cash form due to increasing delay murabahah cash margin realization which will increase main operation income in cash (Utama, 2009, p. i). The researcher drew this conclusion based on several opinions on whether increasing murabahah financing distribution will increase the income originated from murabahah margin which will increase both profit and profitability. $\mathrm{Ha}=$ Murabahah financing quality has positive significant effect on sharia bank ROA.

Bank Indonesia Sharia Certificate (SBIS/ Sertifikat Bank Indonesia Syariah) is the asset of the sharia bank at Bank Indonesia. Sharia bank SBIS buying will affect its assets and bonuses gained from bank Indonesia. Bonuses from Bank Indonesia will increase sharia bank profit and profitability. $\mathrm{Ha}=\mathrm{SBIS}$ has positive effect on sharia bank ROA.

GWM policy as a monetary policy instrument established with the purpose of increasing bank quality. The minimum obligation giro is the minimum funds that should be kept by a sharia bank. The amount is determined by Bank Indonesia with a certain percentage from a third party fund (DPK). GWM will reduce the liquid funds owned by a sharia bank (Teniwut, 2006, p. i). It will affect a sharia bank's financial distribution, as less funds are distributed for financing, less income will be accepted by the sharia bank, which will reduce its profitability. $\mathrm{Ha}=$ GWM has significant negative effect on sharia bank ROA.

Bank financing quality is distinguished into bank probability risk on customer financing obedience in paying profit sharing and fully repaying the financing to the bank. The main elements which determine quality are profit share payment, debt payment, and main financing payment. The better the payment quality (fluent) the better the bank liquidity, as the 
fluent fund accepted by the bank will increase, which will make it easier for the bank to fulfill its liquidity especially in the case of the sudden withdrawal of public funds. Ha: mudharabah financing quality has a positive significant effect on sharia bank QR; while other Ha: musharakah financing quality has a positive significant effect on sharia bank $Q R$ and Ha: murabahah financing quality has a positive significant effect on sharia bank QR.

GWM is savings on DPK put in BI, meaning the GWM is the minimum savings which should be maintained in giro form at Bank Indonesia as a third party fund. The saving is a reservation for the bank when liquidity difficulty emerges (Wijaya, 2005, p. 115). The larger the savings, the higher the bank's liquidity. Ha: GWM has significant positive effect on sharia bank QR.

Liquidity is significant in banking operations. The main priority before re-distributing to the public is to determine the liquid instrument, in cash or giro at Bank Indonesia. The funding allocation in cash post and GWM actually is fulfilling the funding withdrawal from the public. GWM is also primary reservation of bank obligation. Bank Indonesia provides a financing facility for banks having financing difficulties in their business activities, just in case the bank has difficulties in fund distribution and pile up in the bank, then the bank will under over-liquidity. The funding surplus can be temporarily put into Bank Indonesia in the form of SBIS. SBIS is the allocation instrument for over-liquidity funds published and is based on several regulations such as the use of a juialah contract (Solissa, 2009, p. 25). H10= SBIS has positive effect on sharia bank QR.

The profitability measurement used in the banking industry is return on asset (ROA). ROA is used to measure company effectiveness in creating profit using its activa. Larger ROA shows better financial performance due to higher return. Increasing ROA shows bank fluent 
activa will also increase and the bank can fulfill its liquidation more easily. $\mathrm{H} 11=\mathrm{ROA}$ has positive effect on sharia bank QR.

\section{Research Method}

The research population is Islamic banks (BUS/ Bank Umum Syariah). The sampling technique used was purposive sampling. The technique of selecting the sample was chosen carefully and was based on the banks fulfillment of two criteria (Hadi, 2006, p. 75): 1) they were a Islamic bank that published an annual financial report with a note on the financial report; 2) the published financial report fulfilled all elements needed in this research. Based on the criteria the research samples included Bank Syariah Mandiri, Bank Muamalat Indonesia (BMI), Bank Syariah Mega Indonesia (BSMI), Bank Rakyat Indonesia Syariah (BRIS), Bank Syariah Bukopin (BSB), Bank Central Asia Syariah (BCA Syariah), Bank Negara Indonesia Syariah (BNI Syariah), and Bank Jabar Banten Syariah (BJBS).

The research variables are: dependent variable (Return On Asset (ROA) and Quick Ratio (QR)) and independent variable (mudharabah financing quality, musharakah financing quality, murabahah financing quality, SBIS, GWM). The data used in this research are secondary data. The data are from the banks' financial reports, notes on sharia banking financial reports, related references. Researchers often work on the relation among hypothesized variables with large data samples and weak theoretical frameworks. Researchers also often finds highly complex interrelations among the variables with small data sample sizes. Due to the small sample size in this research $(<100)$ the data analysis uses Partial Least Square (PLS). Partial least square (PLS) is an SEM (Structural Equation Modeling) alternative method used to solve the problem of complex relations. PLS assumes the independent distribution of research 
data, meaning research data is not inclined to particular distribution (for example, normal distribution).

PLS is an alternative method with a basic variants approach or model prediction oriented component. PLS works for latent construct relation models and manifest variables (variable manifest or indicator) which are reflective and normative. The purpose of the PLS is to test the predictive relation among the constructs, and to observe the relation or effect among those constructs. The PLS test does not have strong theory, neglects assumptions (is non-parametric), and the prediction model resolves the parameters observed from the determinant coefficient value (R-square) (Latan and Ghozali, 2012, p. 22).

\section{Research Findings}

\section{Model Evaluation}

Structural model is able to be evaluated with $\mathrm{R}^{2}$ (reliable indicator) for the dependent construct and t-statistic value of pattern coefficient test. R-Squares Evaluation

\begin{tabular}{|l|l|}
\hline Variable & R Square \\
\hline ROA & 0.072 \\
\hline QR & 0.75 \\
\hline
\end{tabular}

$\mathrm{R}^{2}$ value for $\mathrm{ROA}$ is 0.072 meaning the variable contribution of mudharabah financing quality (MD), murabahah financing quality (MR), musharakah financing quality, GWM, and SWBI on the ROA variable is 0.072 or $7.2 \%$, with the others were affected by other variables outside the research model. $\mathrm{R}^{2}$ value for ROA is 0.072 meaning it is categorized as small. Therefore, the $\mathrm{R}$-square for $\mathrm{QR}$ is 0.75 meaning mudharabah financing quality (MD), murabahah financing quality (MR), musharakah financing quality, GWM, SWBI, and ROA on QR variable is $75 \%$ and the 
other $25 \%$ are affected by other variables outside the research model. The $\mathrm{R}$-square for the $\mathrm{QR}$ variable is 0.75 and is categorized as strong. Parameter Coefficient

\begin{tabular}{|l|c|}
\hline Parameter Coefficient & \\
ROA $\rightarrow$ Quick Ratio & 0.187014 \\
MD $\rightarrow$ ROA & -0.245031 \\
MD $\rightarrow$ Quick Ratio & 0.024855 \\
MR $\rightarrow$ ROA & 0.181997 \\
$M R \rightarrow$ Quick Ratio & 0.188068 \\
MSY $\rightarrow$ ROA & -0.049053 \\
MSY $\rightarrow$ Quick Ratio & 0.046898 \\
GWM $\rightarrow$ ROA & -0.204052 \\
GWM $\rightarrow$ Quick Ratio & 0.807486 \\
SBIS $\rightarrow$ ROA & -0.086688 \\
SBIS $\rightarrow$ Quick Ratio & 0.092777 \\
\hline
\end{tabular}

Based on the data above on the parameter coefficient: (1). ROA effect on $\mathrm{QR}$ is 0.187 , meaning there is a positive effect of ROA on QR. This means that when ROA increases one unit the $\mathrm{QR}$ value will increase by 0.187 . (2) Mudharabah financing quality effect on ROA is -0.24 , meaning there is a negative effect of mudaarabah financing quality on ROA. This shows that where mudharabah financing quality increases by one unit the ROA value will reduce by 0.24 . (3) Mudharabah financing quality effect on $\mathrm{QR}$ is 0.024 , meaning there is a positive effect of mudharabah financing quality on $\mathrm{QR}$. This shows that when mudharabah financing quality increases one unit ROA value will increase by 0.024 . (4) Murabahah financing quality effect on ROA is 0.18 , meaning there is a positive effect of murabahah financing quality on ROA. This shows that when mudharabah financing quality increases one unit ROA value will 
increase by 0.18 . (5) Murabahah financing quality effect on $\mathrm{QR}$ is 0.188 , meaning there is a positive effect of murabahah financing quality on QR. This means that when murabahah financing quality increases one unit QR value will increase by 0.188 .

(6) Musharakah financing quality effect on ROA is -0.049 , meaning there is a negative effect of musharakah financing quality on ROA. This means that when musharakah financing quality increases one unit ROA value will reduce by 0.049 . (7) Musharakah financing quality effect on QR is 0.046 , meaning there is a positive effect of musharakah financing quality on $\mathrm{QR}$. This means that when musharakah financing quality increases one unit QR value will increase by 0.046. (8) GWM effect on ROA is -0.204 , meaning there is a negative effect of GWM on ROA. This means that when GWM increases one unit ROA value will reduce by 0.204 . (9) GWM effect on QR is 0.807 , meaning there is a positive effect of GWM on $\mathrm{QR}$. This means that when GWM increases one unit $\mathrm{QR}$ value will reduce by 0.807 . (10) SBIS effect on ROA is -0.0866 , meaning there is a negative effect of SBIS on ROA. This means that when SBIS increases one unit ROA value will reduce by 0.086. (11) SBIS effect on QR is 0.092, meaning there is a positive effect of SBIS on QR. This means that when SBIS increases one unit QR value will increase by 0.092 . 
Structural Test

\begin{tabular}{|l|c|c|}
\hline & T-Statistic & T-Table 1\%: 2.431 \\
& & T-Table 5\%: 1.687 \\
T-Table 10\%: 1.304 \\
ROA $\rightarrow$ Quick Ratio & $2.502411^{* * *}$ & Significant \\
MD $\rightarrow$ ROA & $1.891662^{* *}$ & Significant \\
MD $\rightarrow$ Quick Ratio & 0.341486 & Not Significant \\
MR $\rightarrow$ ROA & $2.076716^{* *}$ & Significant \\
MR $\rightarrow$ Quick Ratio & $2.443624 * * *$ & Significant \\
MSY $\rightarrow$ ROA & 0.285265 & Not Significant \\
MSY $\rightarrow$ Quick Ratio & 0.327153 & Not Significant \\
GWM $\rightarrow$ ROA & $1.602932 *$ & Significant \\
GWM $\rightarrow$ Quick Ratio & $9.467468 * * *$ & Significant \\
SBIS $\rightarrow$ ROA & 1.196108 & Not Significant \\
SBIS $\rightarrow$ Quick Ratio & $1.564900^{* *}$ & Significant \\
\hline Explanation: & & \\
$* \quad$ significant 10\% & & \\
$* *$ significant 5\% & & \\
$* * *$ significant $1 \%$ & & \\
\hline
\end{tabular}

H0: independent variable does not have significant effect on dependent variable.

Ha: independent variable has significant effect on dependent variable.

T-table value is 2.434 ( $\mathrm{n}=37$ and $\alpha 1 \%), 1.687$ ( $\mathrm{n}=37$ and $\alpha=5 \%)$, and $1.304(\mathrm{n}=37$ and $\alpha 10 \%)$. When $\mathrm{t}$-calculation $>\mathrm{t}$-table value then $\mathrm{H} 0$ is rejected and $\mathrm{Ha}$ is accepted. 


\section{Understanding Research Findings}

I have tested 11 (eleven) hypotheses. The result is that five hypotheses are rejected and six hypotheses are accepted. The following discussion provides theoretical explanation and empirical support for the hypotheses test results.

H1: Murabahah financing quality has a positive effect on ROA.

The first hypothesis on murabahah financing quality effect on ROA's parameter coefficient value is 0.18 showing murabahah financing quality has a positive effect on ROA. This positive result shows murabahah financing quality will increase sharia banking financial performance authorized by ROA. Significant value (t-calculation) murabahah financing quality is 2.076. This is bigger than the t-statistic $1.68(2.076>1.68)$, meaning murabahah financing quality has significant effect on ROA. Partial least squares (PLS) analysis results show murabahah financing quality has significant positive effect on ROA, meaning the first hypothesis (H1) is accepted. The result of the data analysis and hypothesis test in this research shows murabahah financing quality has significant positive effect on ROA. Better murabahah financing quality will increase the profit from murabahah debt repayment.

$\mathrm{H} 2$ : Mudharabah financing quality has a positive effect on sharia bank ROA.

The second hypothesis on mudharabah financing quality effect on ROA with -0.24 parameter coefficient value shows mudharabah financing quality has a negative effect on ROA. The negative result shows mudharabah financing quality increases will reduce sharia bank financial performance authorized with ROA. Significant value (t-calculation) of mudharabah financing quality is 1.89 , bigger than the t-statistic of 1.68 (1.89>1.68), meaning that the mudharabah financing quality variable has significant effect on ROA. The partial least squares (PLS) analysis result 
shows mudharabah financing quality has significant effect on ROA with a different and negative direction. As such, the second hypothesis (H2) is rejected.

The result of the data analysis and hypothesis test show significant negative relation between mudharabah financing quality and ROA. The test result shows mudharabah financing quality has a negative effect on ROA. This means that a mudharabah financing quality increase will reduce the ROA value. This is due to the fact that mudharabah financing management, which is a component of sharia bank assets, is more complex than other financings, and more expensive. Mudharabah financing requires higher levels of bank caution. There is high possibility that a sharia bank will increase its staff quality by employing technicians and management experts to evaluate and observe business lenders more than a conventional bank. This will increase the sharia bank's expenses needed to maintain its performance. While in the mudharabah system the bank will be responsible for its customers' business losses, sharia general bank income from mudharabah financing distribution is not optimal and they may not be able to pay the expenses. The contribution of profit sharing is not yet able to optimize sharia general banks' ability to create profit the effect of which is the decrease of sharia bank ROA.

$\mathrm{H} 3$ : musharakah financing quality has significant positive effect on sharia bank ROA

The third hypothesis on musharakah financing quality effect on ROA has a parameter coefficient value of -0.05 . This means that musharakah financing quality has a negative effect on ROA. The negative result shows musharakah financing quality will reduce sharia bank financial performance authorized by ROA. The significant value (t-calculation) of musharakah financing quality is 0.28 , is smaller than the t-statistic $(0.28<1.30)$, meaning musharakah financing quality does not have 
an effect on ROA. The partial least squares (PLS) analysis result shows musharakah financing quality does not have significant effect on ROA and has a different direction with negative value, meaning the third hypothesis (H3) is rejected.

The data analysis shows the musharakah financing quality variable has insignificant negative effect on ROA. The result shows musharakah financing quality does not have an effect on sharia bank ROA. The hypothesis test performed is not in accordance with the research stating musharakah financing quality has an effect on ROA. The not-in-accordance is due to the hypothesis test result from the presented hypothesis observed from the banking theory perspective. Based on the bank conceptual perspective, the researcher assumed the not-in-accordance due to the not-in-accordance instrument of musharakah financing quality with the actual condition. This is explained by Bank Indonesia in the 2009 Sharia Banking Study Result Summary which states:

The study result shows profit sharing financing distribution of sharia banking has several applications, namely (i) project basic profit sharing financing (financing project), and (ii) nonproject profit sharing financing in the form of working capital or investment. Every financing distribution application type has different characteristics, therefore, the profit sharing model measurement's optimization will need proper financing for each financing application type.

Based on profit sharing financing characteristics, sharia accountancy principles to measure profit sharing financing activa quality should be categorized based on fund source and financial type. Projects based on musharakah financing should continue using the ratio method of Income Realization (RP/Realisasi Pendapatan)/Income Projection (PP/ Proyeksi Pendapatan). There are two goals of the RP/PP ratio method, namely describing profit sharing realization to be shared with the financing 
customers, and indicating financing in the future. The non-project musharakah should use the RP/PP ratio method by changing the RP/PP threshold in accordance with business financing stages. This is due to the financing exclusion from variable claimed financing, based on sharing revenue with the different character of every business. The financing quality is able to use the Net Asset Value (NAV) method especially in variable claimed financing based on profit-loss sharing. This is the case when a PLS based fund source or financing is not guaranteed to stay permanent or not change.

H4: Minimum Obligation Giro (GWM) has significant negative effect on sharia bank ROA.

The fourth hypothesis shows GWM effect on ROA with parameter coefficient value -0.20 , meaning GWM has negative effect on ROA. This negative result shows an increase in GWM will reduce sharia bank financial performance authorized by ROA. GWM significant value ( $\mathrm{t}$-calculation) is 1.60 , and bigger than the t-statistics of $1.30(1.60>1.30)$, meaning GWM variable has significant effect on ROA. Partial Least Squares (PLS) analysis result shows GWM has significant negative effect on ROA, meaning the fourth hypothesis (H4) is accepted. The data analysis shows GWM has negative significant effect on ROA.

GWM is the function of the Reserve Requirement (RR) in the banking system. GWM is the provision by every bank to save some of the third party funds, collected in the form of minimum obligation giro and saved into a bank giro account at Bank Indonesia. GWM coefficient shows negative value meaning GWM has negative effect on sharia bank ROA. This is due to the GWM at Bank Indonesia reducing allocated DPK in financing to produce profitability. GWM is not a substitution, as SBIS is a banking alternative to gain larger profit than through liquidity surplus utilization. This saving is the bank's reservation when it has liquidity 
difficulty (Wijaya, 2005, p. 9). The larger the GWM saving the higher the sharia bank liquidity ability, however, the idle fund will increase and sharia bank profitability will decrease. The idle fund is the bank's calculation component to create the fund expenses.

H5: Bank Indonesia Sharia Certificate (SBIS) has positive effect on sharia bank ROA

The fifth hypothesis is about SBIS effect on ROA with parameter coefficient value of -0.08 , meaning SBIS has negative effect on ROA. The negative result shows SBIS will reduce sharia bank financial performance authorized by ROA. SBIS significant value (t-calculation) is 1.19 , smaller than the t-statistic of $1.30(1.19<1.30)$. This means that the SBIS variable does not have a significant effect on ROA. Partial Least Squares (PLS) analysis result shows SBIS does not have significant effect on ROA and due to different direction the value is negative. This means the fifth hypothesis (H5) is rejected and SBIS does not affect ROA.

The performed hypothesis test is not in accordance with the research hypothesis stating SBIS has a positive significant effect on ROA. The reasons the hypothesis test is not in accordance with the research hypothesis are: 1) SBIS bonus is not the main factor to determine sharia banks' main operations. Even if the SBIS bonus is high, it is small compared to the income from the main operation. It is a high possibility that SBIS does not affect ROA due to other more dominant factors, namely the sharia bank main operations, such as financing; 2) SBIS is an alternative and substitution to manage liquidity, and is one of several options. The liquidity surplus could be allocated into other investments, such as expense additions and saver SUN buying. This means that SBIS does not affect the determination of sharia bank profitability level.

H6: Murabahah financing quality has a positive significant effect on sharia bank QR. 
The sixth hypothesis is about murabahah financing quality effect on QR with parameter coefficient value of 0.188 , meaning murabahah financing quality has a positive effect on $\mathrm{QR}$. This positive effect shows that a murabahah financing quality increase will increase sharia bank financial performance authorized with QR. Murabahah financing quality significant value (t-calculation) is 2.443 , bigger than the t-statistic of 2.431 (2.443 $>2.431$ ), meaning murabahah financing quality variable has significant effect on QR. Partial Least Squares (PLS) analysis result shows murabahah financing quality has significant positive effect on QR. It means the sixth hypothesis (H6) is accepted.

The research analysis data shows murabahah financing quality has significant positive effect on sharia bank liquidity authorized by QR. Fund allocation in financing has several goals, namely: to achieve standard profitability level and low risk level; and maintain public trust by keeping the liquidity position at save position. Increasing murabahah financing quality will increase bank opportunity to gain fluent activa and is expected to increase liquidity (QR).

H7: Mudharabah financing quality has positive significant effect on sharia bank QR

The seventh hypothesis is about mudharabah financing quality effect on $\mathrm{QR}$ with parameter coefficient value of 0.02, meaning mudharabah financing quality has positive effect on $\mathrm{QR}$. This positive effect shows mudharabah financing quality increases will increase sharia bank financial performance authorized with QR. Mudharabah financing quality significant value ( $\mathrm{t}$-calculation) is 0.34 , smaller than the $\mathrm{t}$-statistic of $1.30(0.34>1.30)$, meaning mudharabah financing quality variable does not have significant effect on QR. Partial Least Squares (PLS) analysis result shows mudharabah financing quality has positive insignificant effect on $\mathrm{QR}$. It means the seventh hypothesis $(\mathbf{H} 7)$ is rejected. 
The data analysis shows mudharabah financing quality has positive insignificant effect on sharia bank liquidity authorized by Quick Ratio (QR). The fund allocation has several goals, namely: proper profitability level and low risk level; and maintaining public trust in keeping the liquidity position safe. Better mudharabah financing quality will increase bank opportunity to gain fluent activa with the expectation of increasing $\mathrm{QR}$. The performed hypothesis test is not in accordance with the presented hypothesis stating mudharabah financing quality affects $Q R$. This is due to the fluent activa component of Quick Ratio. The fluent activa has several accounts such as cash, investment at BI, investment in other banks, securities, loans, and financing. Self financing consists of murabahah, mudharabah, musharakah, ijarah, and istisna'. Mudharabah financing quality variable does not completely affect $\mathrm{QR}$. There is high possibility mudharabah financing quality does not have significant effect on QR.

H8: Musharakah financing quality has a positive significant effect on sharia bank QR.

The eighth hypothesis is about musharakah financing quality effect on QR with a parameter coefficient value of 0.04 , meaning musharakah financing quality has a positive effect on QR. This positive effect shows musharakah financing quality increases will increase shari'ah bank financial performance authorized with QR. Musharakah financing quality significant value (t-calculation) is 0.32 , smaller than the t-statistic of 1.30 $(0.32>1.30)$, meaning the musharakah financing quality variable does not have significant effect on QR. Partial Least Squares (PLS) analysis result shows musharakah financing quality has positive insignificant effect on $\mathrm{QR}$, therefore, the eighth hypothesis (H8) is rejected.

The data analysis shows musharakah financing quality has positive insignificant effect on sharia bank liquidity authorized by Quick Ratio (QR). The performed hypothesis test is not in accordance with the presented 
hypothesis stating musharakah financing quality affects $Q R$. This is due to fluent activa and the fluent obligation component of Quick Ratio which consist of several accounts, such as cash, investment at BI, investment in other banks, securities, loans, and financing. There is high possibility that musyärakah financing quality does not have significant effect on QR.

H9: GWM has positive significant effect on sharia bank QR.

The ninth hypothesis is about GWM effect on QR with parameter coefficient value of 0.80 , meaning GWM has positive effect on QR. This positive effect shows GWM increases will increase shariah bank financial performance authorized with QR. GWM significant value (t-calculation) is 9.46, and bigger than the t-statistic of 2.431 (9.46 > 2.431), meaning GWM variable has significant effect on QR. Partial Least Squares (PLS) analysis result shows GWM has positive significant effect on $\mathrm{QR}$. The ninth hypothesis (H9) is thus accepted.

The data analysis in this research shows GWM has positive significant effect on shari'ah bank liquidity authorized by Quick Ration (QR). GWM is saving of DPK investment at BI, meaning GWM is the minimum saving that should be maintained in the form of giro at Bank Indonesia in a third party fund. The increasing GWM will increase bank liquidity ability, affecting shari'ah bank $\mathrm{QR}$ increases. The positive and significant research result shows GWM is able to be used to mend and increase liquidity. This is in accordance with the theory stated before that GWM has a positive significant effect on QR.

H10: SBIS has significant effect on QR

The tenth hypothesis is about SBIS effect on QR with parameter coefficient value of 0.09 , meaning SBIS has positive effect on QR. This positive effect shows SBIS increases will increase sharia bank financial performance authorized with QR. SBIS significant value (t-calculation) is 1.56 , and bigger than the t-statistic of $1.30(1.56>1.30)$, meaning 
SBIS variable has significant effect on QR. Partial Least Squares (PLS) analysis result shows GWM has a positive significant effect on QR. The tenth hypothesis (H10) is also accepted.

The data analysis in this research shows SBIS has positive significant effect on sharia bank liquidity authorized by Quick Ration (QR). Quick ratio has components of fluent activa and fluent debt. The fluent activa has several accounts such as cash, investment at BI, investment in other banks, securities, loans, and financing. The higher the SBIS the higher fluent activa in the form of investment in Bank Indonesia will increase the quick ratio of the sharia bank.

H11: ROA has significant effect on QR.

The eleventh hypothesis is about ROA effect on $\mathrm{QR}$ with parameter coefficient value of 0.18 , meaning ROA has a positive effect on $\mathrm{QR}$. This positive effect shows ROA increases will increase $Q R$. ROA significant value ( $\mathrm{t}$-calculation) is 2.50 , and bigger than the t-statistic of 2.30 (2.50 > 2.30), meaning the ROA variable has significant effect on QR. Partial Least Squares (PLS) analysis result shows ROA has positive significant effect on QR. This means that the eleventh hypothesis (H11) is accepted.

The data analysis in this research shows ROA has positive significant effect on sharia bank liquidity authorized by Quick Ration (QR). Return on Asset (ROA) is used to measure company effectiveness in producing profit using its activa. The bigger ROA shows better financial performance. The increasing ROA shows increasing bank fluent activa. The increase in fluent activa will make the bank fulfill its liquidity more easily. The positive significant test result shows ROA has a positive effect on QR. Higher ROA shows better financial performance due to higher return repayment level. Increasing ROA will increase bank fluent activa, increasing sharia bank $\mathrm{QR}$ and easing the sharia bank's ability to fulfill its liquidity especially in the case of sudden customer withdrawal. 


\section{Conclusion}

Not all financing quality has sharia bank profitability and liquidity. The only financing quality that affects sharia bank profitability and liquidity is murabahah financing quality. The musharakah financing quality does not have an effect on sharia bank profitability and liquidity. Mudharabah financing quality has a negative effect on sharia bank profitability and does not affect sharia bank liquidity. GWM as a representation of a sharia monetary policy instrument has a negative effect on sharia bank profitability and a positive effect on sharia bank liquidity. Another sharia monetary policy instrument, SBIS, does not affect sharia bank profitability, and has a positive effect on sharia bank liquidity. Profitability has a positive effect on sharia bank liquidity.

Financing quality needs to be increased with stricter financing, proper application and more accurate monitoring. Shariah banks need more innovation to distribute financing under the profit sharing principle in order to attract customers. One of the factors affecting ineffective profit sharing on shari'ah bank profitability and liquidity is the small financing distribution portion using the profit sharing principle. Shari'ah banks should continue increasing financing quality with the muuräbahah trading principle, by distributing and managing it well to improve financing quality and increase shari'ah profitability and liquidity. Shari'ah banks need to attend to other fund distributions to be able to gain return to cover losses due to bad financing. Shari'ah banks also need to be aware of fund distribution to maintain their good standing. 


\section{References}

Bank Indonesia. (2003). Peraturan Bank Indonesia No 5/7/PBI/2003 Tentang Kualitas Aktiva Produktif Bagi Bank Syariah, Jakarta: Bank Indonesia.

Bank Indonesia. (2011). Peraturan Bank Indonesia Nomor 13/13/PBI/2011 Tentang Penilaian Kualitas Aktiva Bagi Bank Umum Syariah dan Unit Usaha Syariah, Jakarta: Bank Indonesia.

Denda, W. L. (2005). Manajemen Perbankan, Jakarta: Ghalia Indonesia.

Dimyati, A. R. (2010), Pengaruh Kualitas Pembiayaan Terhadap

Profitabilitas Perbankan Syariah. Skripsi, Bandung: Universitas Pendidikan Indonesia.

Ermayanti, D. Kinerja Keuangan Perusahaan. http://dwiermayanti. wordpress.com, accessed 16 September 2012.

Hadi, S. (2006). Metode Penelitian Kuantitatif untuk Akuntansi dan Keuangan, Yogyakarta: Ekonisia.

Latan, H., \& Imam G. (2012). Partial Least Squares. Semarang: Badan Penerbit Universitas Diponegoro.

Muhammad. (2004). Manajemen Dana Bank Syariah, Yogyakarta: Ekonisia.

Muljono, T. P. (2002). Aplikasi Manajemen dalam Praktik Perbankan, Yogyakarta: BPFE.

Mulyanto, Y. (2012). Pengaruh Kualitas Pembiayaan Mudharabah, Musyarakah, dan Murabahah Terhadap Rentabilitas PT Bank Syariah Mandiri. Thesis. Bandung: Universitas Pendidikan Indonesia.

Nuriyah S. D. (2009). Pengaruh SBI Syariah Terhadap Tingkat FDR Perbankan Syariah. Thesis. Jakarta: Universitas Indonesia.

PT. Bank Syariah Mega Indonesia. (2010). Annual Report/Laporan Tahunan 2009 Moving on The Right Momentum. Jakarta: PT. Bank 
Syariah Mega Indonesia.

Puspitasari, E. (2011). Pengaruh Kualitas Pembiayaan dan Kebijakan

Moneter Terhadap Kinerja Keuangan Bank Syariah. Thesis. Yogyakarta:

Universitas Islam Negeri Sunan Kalijaga.

Razali, A. (2011). Efektifitas Sertifikat Bank Indonesia Syariah (SBIS)

Terhadap Pengendalian Likuiditas Perbankan Syariah Di Indonesia.

Thesis. Jakarta: Universitas Indonesia.

Rosliana, (2008). Pengaruh Pembiayaan Murabahah Terhadap Return on

Assets (ROA) Pada PT. Bank Muamalat Indonesia. Thesis. Bandung:

Universitas Pendidikan Indonesia.

Simatupang, A. D. R. (2006). Pengaruh SWBI, Kurs dan Inflasi Terhadap Kinerja ROA Bank Muamalat Indonesia pada Januari 2001-Desember 2005. Thesis. Jakarta: Universitas Indonesia.

Shofa, D. E. (2010). Pengaruh Pembiayaan Mudharabah dan Musyarakah Terhadap Profitabilitas Bank Umum Syariah di Indonesia. Thesis. Malang: Universitas Negeri Malan

Suwiknyo, D. (2009). Analisis Laporan Keuangan Perbankan Syariah, Yogyakarta: Pustaka Pelajar.

Teniwut, W. A. (2006). Pengaruh Perubahan Giro Wajib Minimum (GWM) Terhadap Tingkat Kinerja Perbankan Indonesia. Thesis. Bogor: Institut Pertanian Bogor.

Utama, Dayno. (2009). "Hubungan Piutang Murabahah Dengan Bagi Hasil Investasi Tidak Terikat Bank Syariah (Studi Pada Bank Syariah Mandiri) Thesis. Bandung: Universitas Pendidikan Indonesia.

Widyastuti, S. (2009). Penggunaan Variabel Instrumen Moneter Syariah Untuk Menganalisis Perbankan Syariah. Akuntabilitas. Vol. 2. 
Vol. 1 No. 3, September - December 2016 